\section{A workshop for the king}

\author{
Arne Jouttijärvi \\ Heimdal-archaeometry, Virum, Denmark
}

\section{Abstract}

Through the use of single context planning, combined with archaeobotanical and dendrochronological investigations and extensive sampling for archaeometallurgical analysis, it was possible to reconstruct the use of the workshop at Viborg Søndersø in detail. The investigations were made in close cooperation between an archaeologist (Turi Thomsen), an archaeobotanist (Annine Moltsen), a dendrochronologist (Aiofe Daly) and an archaeometallurgist (the author), the last three now members of the Danish Center for Environmental Archaeology. The workshop was erected in 1018 and used a range of different crafts including smithing, casting of silver, bronze and probably lead and comb making. Extensive silver refining apparently took place in nearby workshops. The use of the excavated workshop was a seasonal activity in the winter months and during summer only occasional repair work was done to the building. After three years of activity, the building was kept in repair for another two years and then finally torn down. It is argued that the workshop was probably established in connection with the crowning of King Canute to king of Denmark in 1018 and the minting of the Dane-geld to Danish coins. The workshop might have been used during the yearly meeting of the Thing in Viborg.

\section{Introduction}

The excavation at Viborg Søndersø was conducted in 2001 with the aim to develop new interdisciplinary research and working methods - and thereby define new standards and standards for archaeological excavation and research in Danish cities in the future. The site was chosen because preservation conditions here were ideal and the object was of such a nature that it would most likely be possible to get a detailed insight into the style of building, equipment, distribution of finds and technology. Moreover, it was important to be able to work in a multidisciplinary manner with pre-set questions about living conditions, resource and cultural environment, etc.

Viborg is located in the middle of Jutland, the main watershed of the northwest corner of the ice front. Southwest of the city lies the large flat moorland, while moraine landscape to the north and east is hilly with numerous valleys radiating into the city. Since the passages previously to some extent followed the water divisions, Viborg was a natural traffic junction in Jutland and thus a religious and administrative center.

\section{Materials and Methods}

Due to subsequent damming up of the adjacent Viborg Soendersoe the remains of the workshop were found in a water-soaked layer, resulting in the organic material being well preserved. The excavation was carried out by the single-context method, resulting in almost ideal conditions for the systematic sampling of the individual layers (Thomsen, 2005). The layers of sand and debris within the building were all sampled in a grid with a side length of $25 \mathrm{~cm}$ resulting in the collection of a total of around 700 samples each weighing between 50 and $100 \mathrm{~g}$. A standard procedure for the sorting of different types of waste present in each sample was applied. Each sample was sieved into fractions with grain sizes of $>5,2$ to 5 , and $<2 \mathrm{~mm}$. Charcoal was removed from the two largest fractions by flotation and after drying slag, hammerscale and slag spheres were removed by magnet and sorted manually. Pieces of burned or vitrified clay, molten clay droplets, crucibles, lead droplets unmagnetic spheres etc. were sorted out manually.

Finally each resulting fraction was weighed and the relative weight compared to the original dried sample weight was calculated. The manual processing of the samples was reduced somewhat, since only a few samples were tested from each of the sand layers. From selected samples hammerscale, slag and other materials were taken out for chemical analysis.

Even small pieces of wood were well preserved and therefore suitable for dating, and as the layers were to a large degree intact, the activity could often be dated not only to a specific year but even to a season (Daly, 2005). These datings were supported by studies of plant roots, seeds and other traces of growth layers (Moltsen, 2005).

\section{Results and Discussion}

After the death of his father Sweyn Forkbeard, Canute won the throne of England in 1016. After his brother Harald II died in the year 1018 king Canute returned from England to be crowned king of Denmark. It is told that he paid off his fleet with a huge amount of silver, almost 30,000 kg, collected as Dane-geld, and he probably brought huge amounts of silver to Denmark for the production of coins.
Correspondence: Arne Jouttijärvi, Heimdalarchaeometry, Skovledet 30, 2830 Virum, Denmark.

Tel/Fax: +45.45.85.72.70.

E-mail: heimdal@archaeometry.dk

Key words: workshop, king, Denmark.

Citation: Jouttijärvi A, 2014. A workshop for the king. In: RH Tykot (ed.), Proceedings of the $38^{\text {th }}$ International Symposium on Archaeometry - May $10^{\text {th }}-14^{\text {th }} 2010$, Tampa, Florida. Open Journal of Archaeometry 2:5459.

Presented at the $38^{\text {th }}$ International Symposium on Archaeometry - May $10^{\text {th }}-14^{\text {th }} 2010$, Tampa, Florida.

This work is licensed under a Creative Commons Attribution 3.0 License (by-nc 3.0).

(C) Copyright A. Jouttijärvi, 2014

Licensee PAGEPress, Italy

Open Journal of Archaeometry 2014; $2: 5459$

doi:10.4081/arc.2014.5459

Coins of King Canute were minted in nine Danish mints from 1018. One of these is known to have been situated in Viborg in the central part of Jutland (Figure 1). It was also the gathering place of one of the three Things of Denmark, one of the places where Canute must have been elected as king.

In Viborg a building was erected in the winter of 1018-19 or at least part of the timber that was used, was felled this winter. Slag, charcoal and vitrified clay in some of the earliest layers in the building indicate that the workshop may initially have been a traditional Viking Age smithy with a forge at ground level. The next year the building was equipped with a raised forge constructed as a wooden sand filled box with a side length of about $1 \mathrm{~m}$.

In the winter of 1019-20, or early in 1020 , a heap of sand was thrown into the middle of the building, probably to be used as fill in the raised forge (Figure 2). Some of the sand was left on the floor during the summer of 1020, a period in which no activity took place in the workshop, as there is evidence that weeds grew in the sand. Chips of wood from the anvil foundation came from the same piece of tree trunk, as the posts that were used as corners of the forge. This tree had been felled in the spring or early summer of 1020 .

The forge was preserved to a height of app. $30 \mathrm{~cm}$, and the original height is not known. It might have been a full height waist level forge with the smith standing, but it is also possible that the forge was not much higher than the 30 $\mathrm{cm}$ and the blacksmith was sitting either on the floor or on a low stool. According to contemporary illustrations it was quite normal for the blacksmith to be sitting at his work from 


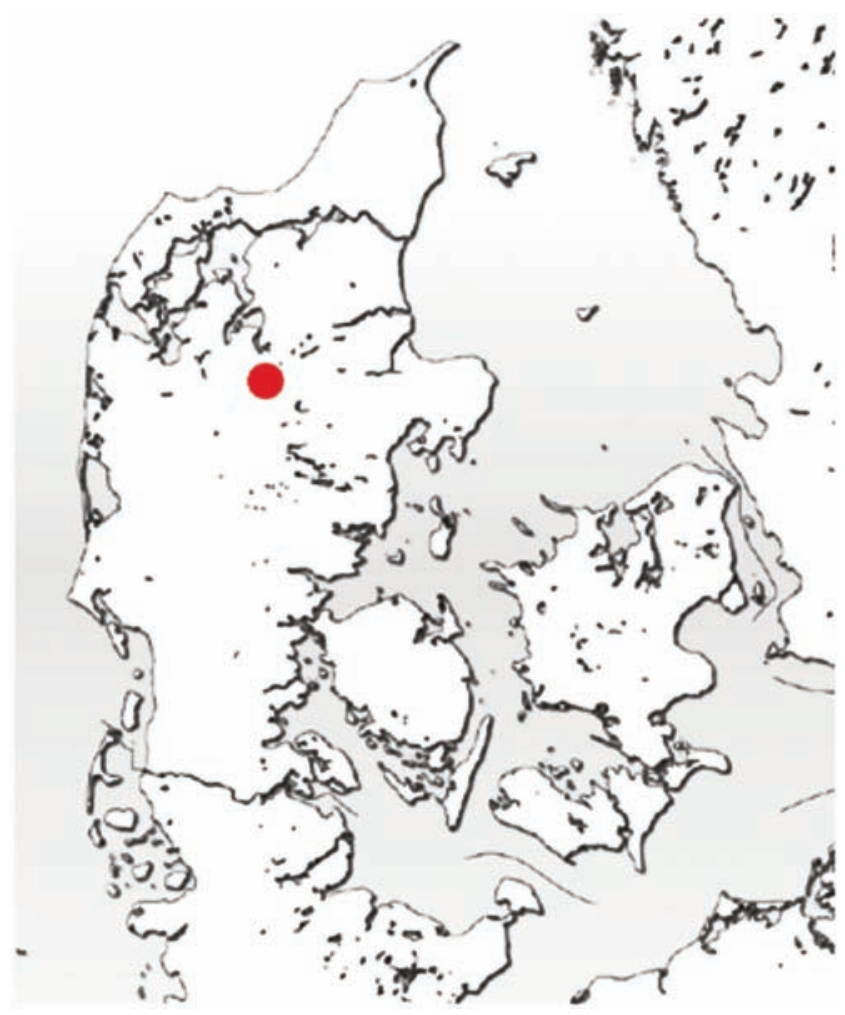

Figure 1. Viborg's location (red circle) in Jutland.

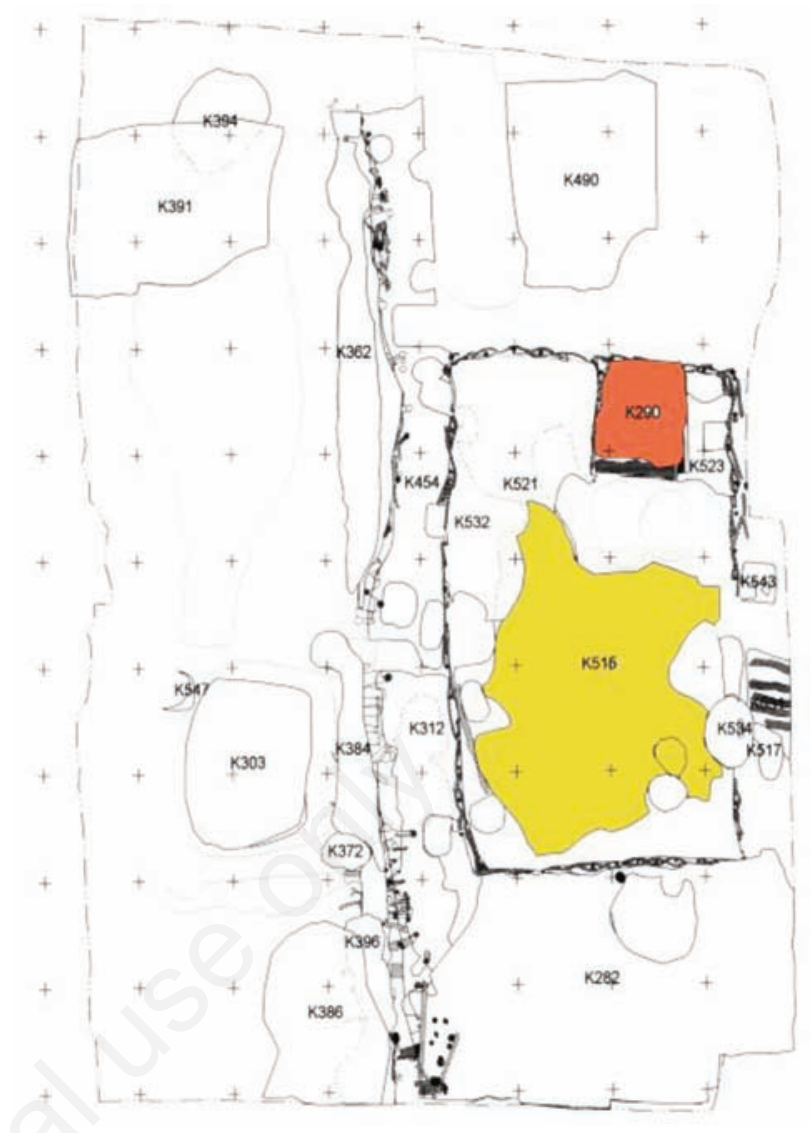

Figure 2. The layout of the workshop showing the forge (red) and the first layer of sand (yellow). the Roman Iron Age and until the medieval period. Seated smiths can still be seen at least until the $15^{\text {th }}$ century. The blacksmith's position probably depended on the size of the objects he worked on. Major works required stronger strokes and thus that the blacksmith worked standing.

There is not much evidence for low level forges, and it seems more likely that the forge was at waist-level as illustrated in the $12^{\text {th }}$ century wood carving from a church at Hylenstad in Norway (Figure 3). Even here the position of the blacksmiths legs indicates that he is probably sitting on a chair or stool.

At the same time as the forge was erected, a large wooden block was partly buried in front of it to serve as base for the anvil.

The building itself was constructed with braided walls of hazel, and the distributions of the weeds growing in the sand shows that the walls were not completely sealed, since light could penetrate through them. Probably the south gable was left partly open as later layers showed a pronounced growth of weed in this end of the workshop. This was most likely a deliberate construction, as the light from the open gable made it possible for the craftsmen to perform functions or crafts for which light was needed while the other end of the workshop was still shrouded in darkness which is the best by forging and casting, where it is important to recognise the color of the glowing metal.

In the autumn of 1020 another layer of sand was spread inside the workshop, probably to level the floor in preparation for the craftsmen arriving in the autumn or winter of 1020-1021. During this winter period, iron blooms, probably imported from Southern Germany or Central Europe, were refined in the workshop, as demonstrated by the presence of primary smithing slag.

A large, almost square, concentration of larger pieces of charcoal in the south-western corner of the workshop is interpreted as the remains of a square booth used for storage of fuel (Figure 4). A diagonal footpath within this booth is marked by crushed charcoal and an elevated concentration of crushed hammerscale, transported here from the vicinity of the anvil by the craftsmen as they walked back and forth to get the charcoal to the forge (Figure

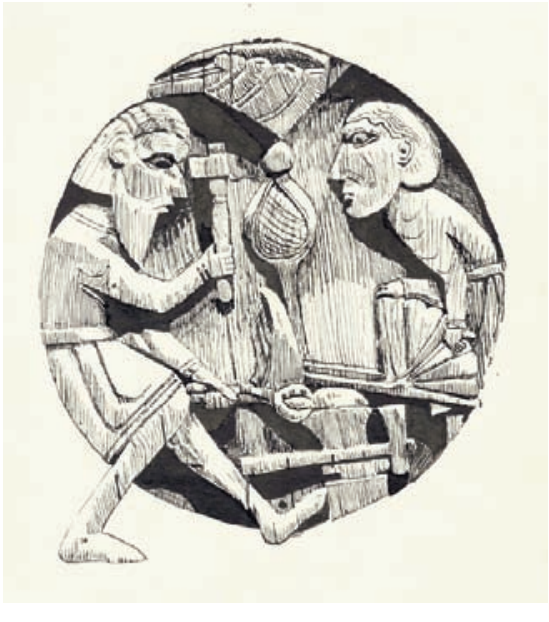

Figure $3 . \mathrm{A} 12^{\text {th }}$ century revised illustration of a smithy. Wood carving from a church at Hylenstad, Norway. Reproduced with permission of Dr. Paulsen: http://www.ovepaulsen.dk/vaesener/reginsmeder-gram-til-sigurd-fafnersbane/ 
5). A concentration of small rectangular pieces of iron in the south-eastern corner of the booth indicates the presence of a box or barrel used for storing iron.

The presence of crucible fragments shows that the workshop was also used for casting silver. Apparently this was part of silver refining and casting on a rather large scale, as evidenced by numerous finds of crucibles and scorifiers (crucibles for the assaying or refining of silver or gold) in the area. The refining of silver must have taken place in nearby work- shops, and only occasionally some of the silver was cast within this workshop. The large scale of the silver working could indicate that the workshops in Viborg was established in connection with the processing of the Dane-geld brought by king Canute, and the subsequent minting of the silver.

From time to time the forge was cleaned or rebuilt. The debris was heaped in the southeastern corner and later dumped to the north of the building. In this layer a fragments of scorifiers with black vitrified inside were found together with pieces of what appeared to be lining originally applied inside other scorifiers. Chemical analysis of the clay of the scorifiers and the linings showed that the clay scorifiers were probably made from local clay of a usual composition, whereas the linings had a very high content of phosphorous oxide and calcium oxide (Table 1). The linings were probably made from ash mixed with a small amount of clay, and the ratio between calcium and phosphorous indicates that the ash most likely came from wood (Marcos Martinon-

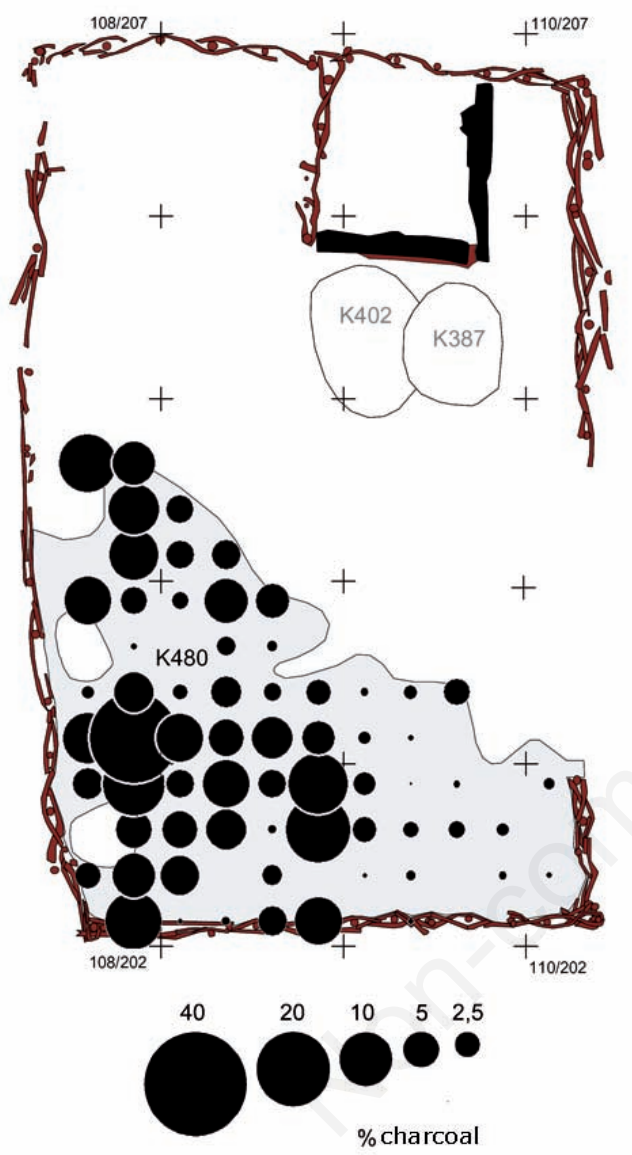

Figure 4. The concentration of large pieces of charcoal in the south western corner of the building.

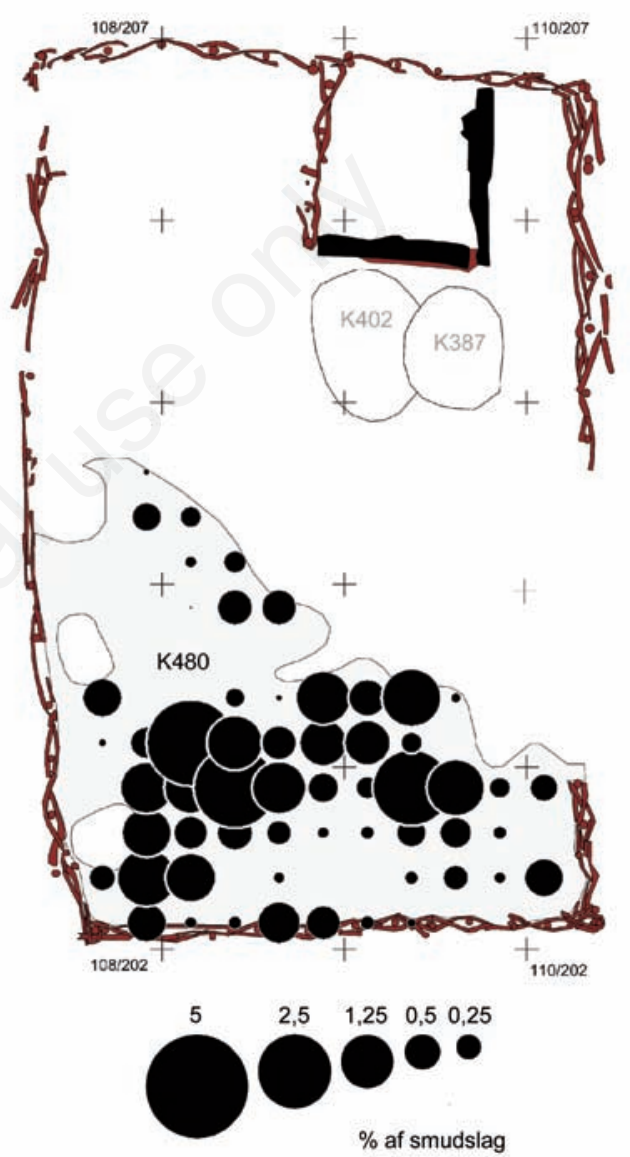

Figure 5. Diagonal footpath of crushed hammerscale.

Table 1. Chemical analysis of the clay of the scorifiers and the linings.

\begin{tabular}{|c|c|c|c|c|c|c|c|c|c|c|c|c|c|}
\hline Number & Type & $\begin{array}{c}\text { Thickness } \\
\text { (mm) }\end{array}$ & $\begin{array}{c}\text { Metals } \\
\text { identified }\end{array}$ & $\begin{array}{c}\mathrm{Na}_{2} \mathrm{O} \\
\%\end{array}$ & $\begin{array}{c}\mathrm{MgO} \\
\%\end{array}$ & $\begin{array}{c}\mathrm{Al}_{2} \mathrm{O}_{3} \\
\%\end{array}$ & $\begin{array}{c}\mathrm{SiO}_{2} \\
\%\end{array}$ & $\begin{array}{c}\mathrm{P}_{2} \mathrm{O}_{5} \\
\%\end{array}$ & $\begin{array}{c}\mathrm{K}_{2} \mathrm{O} \\
\%\end{array}$ & $\begin{array}{c}\mathrm{CaO} \\
\%\end{array}$ & $\begin{array}{c}\mathrm{TiO}_{2} \\
\%\end{array}$ & $\begin{array}{c}\mathrm{Mn0} \\
\%\end{array}$ & $\begin{array}{c}\mathrm{FeO} \\
\%\end{array}$ \\
\hline x3356 & Scorifier & $3-4$ & $\mathrm{~Pb}, \mathrm{Cu}, \mathrm{Ag}$ & 3.2 & 1.8 & 12.6 & 57.0 & 0.3 & 3.2 & 1.6 & 0.9 & 0.0 & 14.6 \\
\hline x3736 & Scorifier & $3-4$ & $\mathrm{~Pb}, \mathrm{Cu}$ & 4.6 & 1.1 & 19.2 & 57.1 & 0.5 & 2.6 & 0.4 & 3.7 & 0.0 & 11.9 \\
\hline x3736 & Scorifier & $10-11$ & $\mathrm{~Pb}, \mathrm{Ag}$ & 4.1 & 2.1 & 11.9 & 62.3 & 0.7 & 2.8 & 0.8 & 1.7 & 0.2 & 15.9 \\
\hline x3905 & Scorifier & 10 & $\mathrm{~Pb}, \mathrm{Cu}, \mathrm{Ag}$ & 0.6 & 0.4 & 14.2 & 63.0 & 0.5 & 3.3 & 1.2 & 1.2 & 0.1 & 9.4 \\
\hline x3905 & Scorifier & 8-10 & $\mathrm{Pb}, \mathrm{Cu}$ & 0.7 & 0.2 & 8.0 & 70.5 & 0.5 & 2.0 & 1.1 & 0.9 & 0.2 & 7.6 \\
\hline x3825 & Scorifier & $9-10$ & $\mathrm{~Pb}, \mathrm{Ag}$ & 0.8 & 0.1 & 10.1 & 69.0 & 0.5 & 2.8 & 1.4 & 1.1 & 0.0 & 12.0 \\
\hline x2849 & Lining & 7 & $\mathrm{~Pb}, \mathrm{Cu},(\mathrm{Ag})$ & 2.8 & 0.8 & 1.8 & 21.6 & 4.5 & 0.9 & 47.0 & 0.4 & 0.5 & 1.9 \\
\hline$\times 4020$ & Lining & $4-5$ & $\mathrm{~Pb}, \mathrm{Cu},(\mathrm{Ag})$ & 1.0 & 0.5 & 2.6 & 17.9 & 8.2 & 0.6 & 45.0 & 0.3 & 0.6 & 2.5 \\
\hline
\end{tabular}


Torres, personal communication).

There were also traces of water in the workshop. In a region at the western wall the sand was deposited in thin layers suggesting that it had repeatedly been affected by water. It is possible that this marks the location of a bucket or tub of water used for the cooling of tools and the hardening of steel.

Based on the distribution of residue and the structure of the layers, a reconstruction of the layout of the workshop was made (Figure 6).

At some time in early 1021, the craftsmen finished their work and left the workshop. As in the previous year, the summer was a period of idleness apart from the rebuilding of the roof construction. New posts, felled in the spring or early summer of 1021, were added to the walls and a uniform growth of weeds all over the floor indicates that the building was roofless during the summer.

When the rebuilding was complete, the craftsmen again appeared in the autumn/winter of 1021-1022, but now the organisation of the workshop was somewhat altered. The dis- tribution of magnetic material and charcoal (Figure 7) indicates that a large box or chest was now placed in the south-western corner of the workshop. As during the previous season, iron blooms were worked and steel produced. Again silver was cast as shown by the crucible fragments, but new craftsmen also entered the workshop - crucibles from bronze casting have been found, and numerous antler fragments indicate the presence of a combmaker.

The crucibles used for silver and copper alloys differed in composition. Copper alloy crucibles were made from clay with a relatively low content of alumina as it is also seen in the supposedly local clay used for tuyeres. $0 n$ the other hand the clay used for silver casting was of a more refractory type with relatively high alumina content (Table 2). Clay of this composition is not found in Jutland, and was probably imported either as raw clay or as finished crucibles. Imported clay might also be found in one group of low refractory crucibles as they differ from the local clay in having a higher content of titanium oxide. The bronze caster may have brought a stock of its own crucibles, and when they were used was forced to use the local clay for the manufacture of new. The relatively high contents of sodium oxide and iron oxide are probably due to absorption of water from the surroundings.

Production again came to a halt at some time in the spring of 1022 and the workshop was once more abandoned, but this time the door was not closed properly. The analyses of soil samples show that the leaves, twigs and catkins were swept through the open doorway and into the workshop by the wind, and plants grew in the light. Stray animals, probably sheep or goats, also entered the building leaving behind them small heaps of faeces. This indicates that neither the blacksmith, the bronze caster nor the silver caster were present in Viborg during the summer. It is doubtful if any craftsman would have allowed an animal to enter his workshop. No major repairs were carried out on the building this summer.

In the winter of 1022-1023 the workshop was again used for iron-working and the casting of

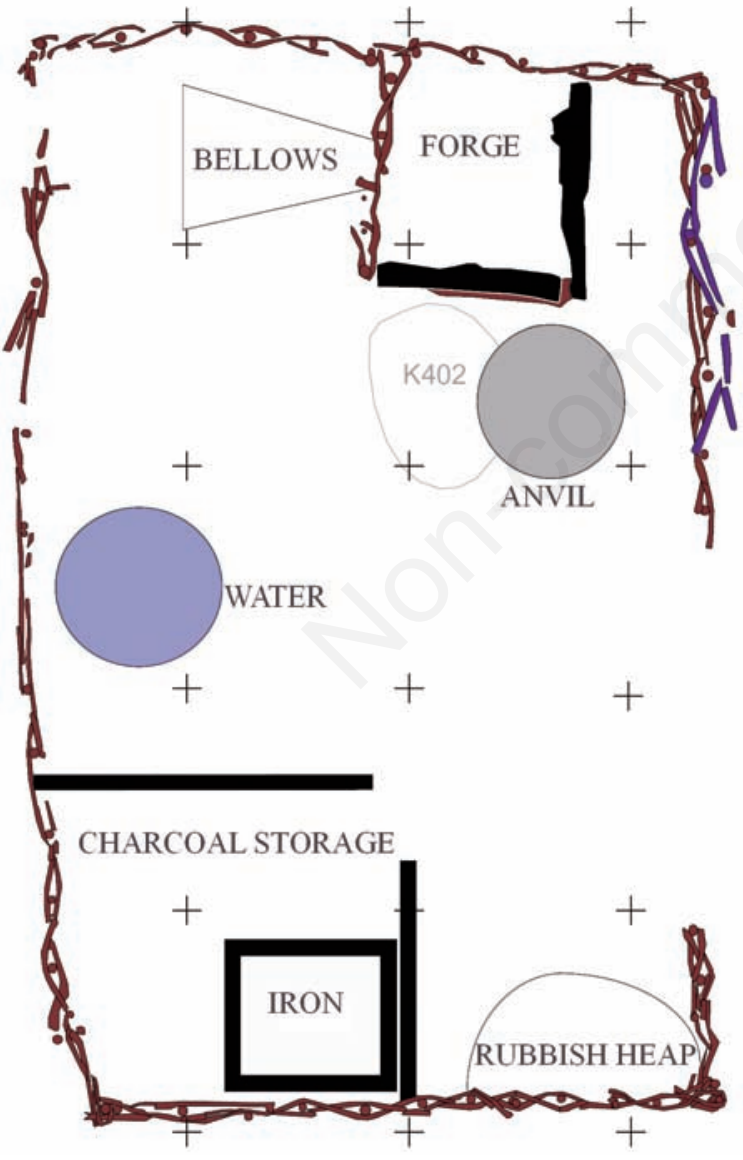

Figure 6. Reconstructed layout of the workshop in the winter 1020-1021.

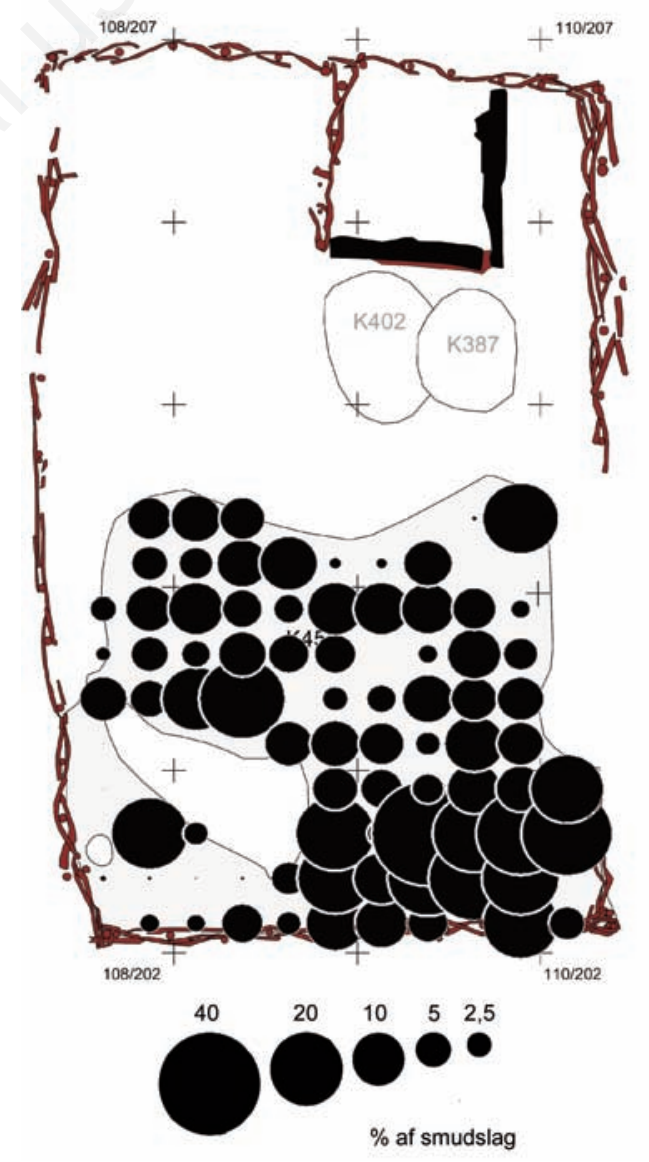

Figure 7. The distribution of charcoal in the winter season 10211022. An empty square confirms the impression that a box or chest was located in the south-western corner. Many large pieces of charcoal indicate that the stock of fuel was moved to the south-eastern corner of the workshop. 
Table 2. Chemical analysis of the clay used for copper alloy and silver casting.

Number Metal $\quad \mathrm{Na}_{2} \mathrm{O}(\%) \quad \mathrm{MgO}(\%) \quad \mathrm{Al}_{2} \mathrm{O}_{3}(\%) \quad \mathrm{SiO}_{2}(\%) \quad \mathrm{P}_{2} \mathrm{O}_{5}(\%) \quad \mathrm{K}_{2} \mathrm{O}(\%) \quad \mathrm{CaO}(\%) \quad 71 \mathrm{O}_{2}(\%) \quad \mathrm{MnO}(\%) \quad \mathrm{FeO}(\%)$

\begin{tabular}{|c|c|c|c|c|c|c|c|c|c|c|c|}
\hline 526 & $\mathrm{Cu}$ & 0.4 & 0.0 & 5.6 & 75.7 & 0.8 & 1.0 & 1.7 & 0.6 & 0.2 & 5.6 \\
\hline 617 & $\mathrm{Cu}$ & 0.0 & 0.0 & 14.1 & 54.0 & - & 2.1 & 0.4 & 1.1 & 0.1 & 7.6 \\
\hline 999 & $\mathrm{Cu}$ & 7.4 & 2.0 & 11.2 & 64.6 & 1.5 & 2.6 & 1.7 & 1.1 & 0.0 & 7.5 \\
\hline 999 & $\mathrm{Cu}$ & 2.4 & 1.1 & 14.2 & 59.2 & 0.9 & 2.8 & 1.5 & 1.3 & 0.2 & 6.6 \\
\hline 1711 & $\mathrm{Cu}, \mathrm{Zn}$ & 3.8 & 1.0 & 15.2 & 56.3 & 0.5 & 6.0 & 2.9 & 0.9 & 0.1 & 2.5 \\
\hline 1793 & $\mathrm{Cu}$ & 0.0 & 0.0 & 6.3 & 82.5 & - & 0.9 & 1.6 & 0.5 & 0.0 & 2.4 \\
\hline 2368 & $\mathrm{Cu},(\mathrm{Zn})$ & 5.5 & 1.6 & 12.3 & 64.7 & 0.2 & 2.8 & 1.0 & 1.0 & 0.1 & 8.6 \\
\hline 3818 & $(\mathrm{Cu})$ & 3,7 & 1,2 & 6.8 & 65.5 & 1.2 & 2.6 & 1.2 & 1.2 & 0.0 & 14.3 \\
\hline 3925 & $\mathrm{Cu}, \mathrm{Pb}$ & 1,9 & 1,7 & 14.9 & 64.5 & 0.2 & 3.1 & 1.0 & 1.2 & 0.1 & 9.7 \\
\hline 4033 & $\mathrm{Cu},(\mathrm{Zn})$ & 2,4 & 1,2 & 11.5 & 66.2 & 0.1 & 2.8 & 1.4 & 0.9 & 0.1 & 9.0 \\
\hline 3864 & $\mathrm{Cu}$ & 3,5 & 1,6 & 7.3 & 71.9 & 0.8 & 2.7 & 1.1 & 3.7 & 0.3 & 7.0 \\
\hline 3864 & $\mathrm{Cu}$ & 3.6 & 1.1 & 7.8 & 55.4 & 2.0 & 2.7 & 2.3 & 3.5 & 0.1 & 13.9 \\
\hline 3864 & $\mathrm{Cu}$ & 4.0 & 1.5 & 6.4 & 71.9 & 1.0 & 2.5 & 1.3 & 3.1 & 0.0 & 6.6 \\
\hline 3905 & $\mathrm{Cu}, \mathrm{Zn}, \mathrm{Pb}$ & 2.4 & 1.1 & 9.1 & 76.1 & 0.0 & 1.9 & 1.1 & 0.8 & 0.1 & 5.1 \\
\hline 3825 & $\mathrm{Cu}$ & 0.4 & 0.0 & 7.9 & 67.6 & - & 2.0 & 1.2 & 0.7 & 0.3 & 11.1 \\
\hline 3673 & $\mathrm{Cu}$ & 0.0 & 0.7 & 16.2 & 61.1 & 1.7 & 4.3 & 2.2 & 1.8 & 0.2 & 11.9 \\
\hline 4023 & $(\mathrm{Cu})$ & 0.0 & 0.0 & 8.8 & 71.3 & & 2.5 & 1.0 & 0.8 & 0.2 & 10.7 \\
\hline 3772 & $\mathrm{Cu}$ & 2.9 & 0.9 & 3.5 & 51.4 & 0.4 & 1.4 & 1.2 & 3.7 & 0.0 & 5.1 \\
\hline 3772 & $\mathrm{Cu}$ & 3.3 & 1.6 & 8.8 & 64.8 & 0.7 & 2.8 & 2.0 & 4.7 & 0.1 & 9.5 \\
\hline 3822 & $\mathrm{Ag}$ & 4.1 & 1.5 & 19.3 & 45.4 & 1.6 & 4.0 & 5.8 & 1.4 & 0.4 & 7.0 \\
\hline 3806 & $\mathrm{Ag}$ & 1.4 & 0.9 & 18.8 & 55.7 & 0.1 & 2.5 & 1.4 & 1.1 & 0.1 & 9.8 \\
\hline 3925 & $\mathrm{Ag},(\mathrm{Cu}),(\mathrm{Zn})$ & 1.2 & 0.7 & 22.2 & 60.6 & 0.2 & 2.6 & 1.2 & 1.2 & 0.1 & 7.9 \\
\hline 3948 & $\mathrm{Ag}$ & 3.0 & 1.2 & 18.7 & 62.2 & 0.5 & 2.7 & 1.2 & 3.5 & 0.0 & 8.2 \\
\hline 4015 & $\mathrm{Ag}$ & 8.9 & 1.1 & 17.9 & 58.9 & 1.4 & 1.6 & 1.7 & 1.3 & 0.3 & 4.4 \\
\hline 3871 & $\mathrm{Ag}$ & 1.2 & 0.0 & 17.4 & 42.8 & - & 4.7 & 6.0 & 0.9 & 0.3 & 16.2 \\
\hline 3871 & $\mathrm{Ag}$ & 0.0 & 0.0 & 13.8 & 75.9 & - & 1.5 & 0.3 & 0.8 & 0.1 & 5.2 \\
\hline 3806 & $\mathrm{Ag}$ & 1.4 & 0.9 & 18.8 & 55.7 & 0.1 & 2.5 & 1.4 & 1.1 & 0.1 & 9.8 \\
\hline 3767 & $\mathrm{Ag}$ & 1.6 & 1.3 & 21.7 & 64.8 & 0.7 & 3.4 & 1.5 & 4.0 & 0.1 & 6.8 \\
\hline 3843 & $\mathrm{Ag}$ & 1.3 & 0.8 & 24.6 & 63.0 & 0.0 & 2.9 & 0.1 & 1.1 & 0.0 & 5.5 \\
\hline 4009 & $\mathrm{Ag},(\mathrm{Cu}),(\mathrm{Zn})$ & 2.0 & 1.2 & 10.8 & 69.4 & 0.2 & 2.4 & 1.5 & 0.9 & 0.1 & 7.4 \\
\hline 3356 & $\mathrm{Ag}$ & 2.2 & 0.9 & 18.2 & 63.7 & 0.2 & 2.8 & 0.5 & 1.6 & 0.1 & 8.4 \\
\hline 3356 & $\mathrm{Ag}$ & 2.8 & 1.2 & 16.6 & 64.2 & 1.3 & 2.4 & 0.5 & 1.8 & 0.0 & 4.9 \\
\hline 3508 & $\mathrm{Ag}, \mathrm{Cu}$ & 3.5 & 1.1 & 18.6 & 63.5 & 0.9 & 2.8 & 0.5 & 2.7 & 0.2 & 6.3 \\
\hline 3508 & $\mathrm{Ag}, \mathrm{Cu}$ & 3.3 & 1.5 & 27.4 & 51.7 & 0.4 & 3.5 & 0.5 & 1.8 & 0.1 & 10.0 \\
\hline 3508 & $\mathrm{Ag}, \mathrm{Cu}$ & 2.9 & 1.0 & 20.2 & 57.9 & 0.0 & 3.1 & 0.2 & 3.8 & 0.4 & 10.0 \\
\hline 3736 & $\mathrm{Ag}$ & 4.7 & 1.0 & 12.4 & 73.7 & 0.6 & 1.2 & 0.8 & 1.6 & 0.0 & 3.4 \\
\hline 3736 & $\mathrm{Ag}$ & 4.7 & 1.0 & 12.4 & 73.7 & 0.6 & 1.2 & 0.8 & 1.6 & 0.0 & 3.4 \\
\hline 3736 & $\mathrm{Ag}$ & 5.2 & 1.0 & 19.1 & 61.5 & 0.6 & 2.7 & 0.4 & 2.7 & 0.1 & 5.6 \\
\hline 2902 & $(\mathrm{Ag})$ & 2.7 & 0.4 & 22.3 & 64.7 & 0.8 & 2.3 & 0.3 & 2.6 & 0.2 & 3.3 \\
\hline 2902 & $(\mathrm{Ag})$ & 2.7 & 0.4 & 22.3 & 64.7 & 0.8 & 2.3 & 0.3 & 2.6 & 0.2 & 3.3 \\
\hline 1854 & $\mathrm{Au}$ & 0.2 & 0.0 & 23.5 & 48.3 & - & 0.6 & 13.6 & 0.6 & 0.2 & 5.8 \\
\hline 2692 & $\mathrm{~Pb},(\mathrm{Cu})$ & 2.7 & 1.2 & 18.7 & 64.6 & 0.9 & 3.1 & 0.8 & 1.4 & 0.2 & 7.2 \\
\hline 4013 & $\mathrm{~Pb}$ & 1.6 & 1.1 & 27.5 & 57.4 & 0.2 & 2.8 & 0.4 & 1.4 & 0.1 & 5.6 \\
\hline 3953 & $\mathrm{~Pb}$ & 3.4 & 1.1 & 16.0 & 57.8 & 0.8 & 2.7 & 1.9 & 1.2 & 0.0 & 9.6 \\
\hline
\end{tabular}


silver and bronze. This seems to be the period of most intense use, leaving a layer of debris almost $7 \mathrm{~cm}$ in thickness. As this layer was preserved across the entire building, it gives detailed information about the organisation of the workshop. As expected, hammerscale and other magnetic material is concentrated around the anvil, but was also transported to the north-western corner of the workshop by the craftsman working the bellows and towards the southern end, where the light was brighter due to the open gable. Hammerscale transported by movement tend to be more crushed than the ahmmerscal around the anvil. The blacksmith himself shielded the floor where he stood, leaving his shadow in the distribution of hammer scale (Figure 8).

The debris is totally absent in a rectangular area in the southwestern corner of the workshop, indicating that this corner was still occupied by the box or chest. It was probably used as a work table as can be seen by the distribution of lead droplets (Figure 9). The lead seems to spread out from the box or chest, and probably a craftsman was sitting in the light from the open gable melting lead. The exact purpose of the lead is not known. It might have been used for the casting of objects, but lead might also have served for the filling of thin walled bronze castings or in connection with cupellation of silver. One refractory crucible found besides the forge did even show traces of lead and not of any other metals. Perhaps lead was melted in the crucibles to test them so that they would not crack when they were used for melting of the much more valuable silver.

In early 1023 the craftsmen left the workshop for the last time and weeds again had the possibility to germinate and grow within the building. As the growth is uniform throughout the layer, the roof again seems to have been removed. Activities in the area meant that the terrain around the workshop gradually became higher because of the deposit of waste. This may be the reason that at some point, possibly beginning in the summer of 1023 , the floor of the workshop was raised almost $16 \mathrm{~cm}$ by the addition of around 20 layers of sand. The addi- tion of sand layers is likely to have continued for two years.

During 1023 and 1024 the building was apparently kept in good repair, but there is no indication that the blacksmith, the silversmith or the bronze caster ever returned. During this period new sand layers were spread on the floor several times and the roof was reestablished. At some time in 1024 it seems that the roof was again removed or blew down. Rainwater now affected the surface of the sand and washed pieces of charcoal down from the forge. Apparently the roof was again restored when the last sand layer was added. In this remains of indoor living spiders were found (Kenward, 2005).

At last the workshop was demolished, the sand from the hearth was used for leveling the terrain and a new building was erected, probably during the course of 1025 . The posts of this building were made from trees felled in the winter of 1024-1025. No workshop debris was found in this building, and it was probably never used for smithing or casting.

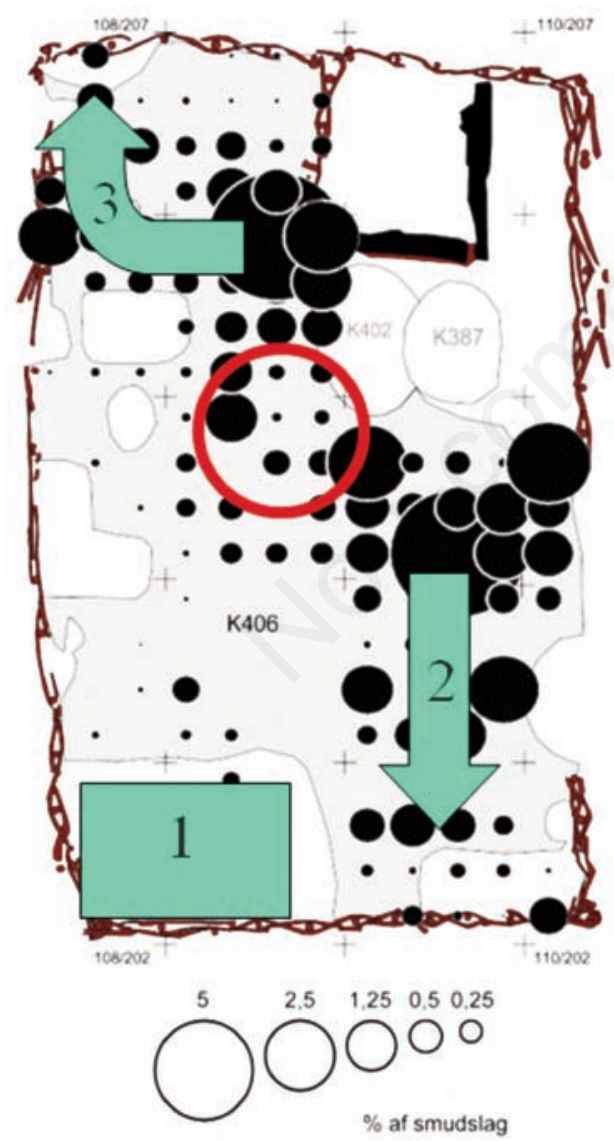

Figure 8. Movement in the workshop in the winter 1022-1023 as indicated by the distribution of hammerscale: 1) chest or box; 2) movement towards the light from the open gable; 3 ) movement by the man working the bellows. Red circle represents the shadow of the blacksmith.

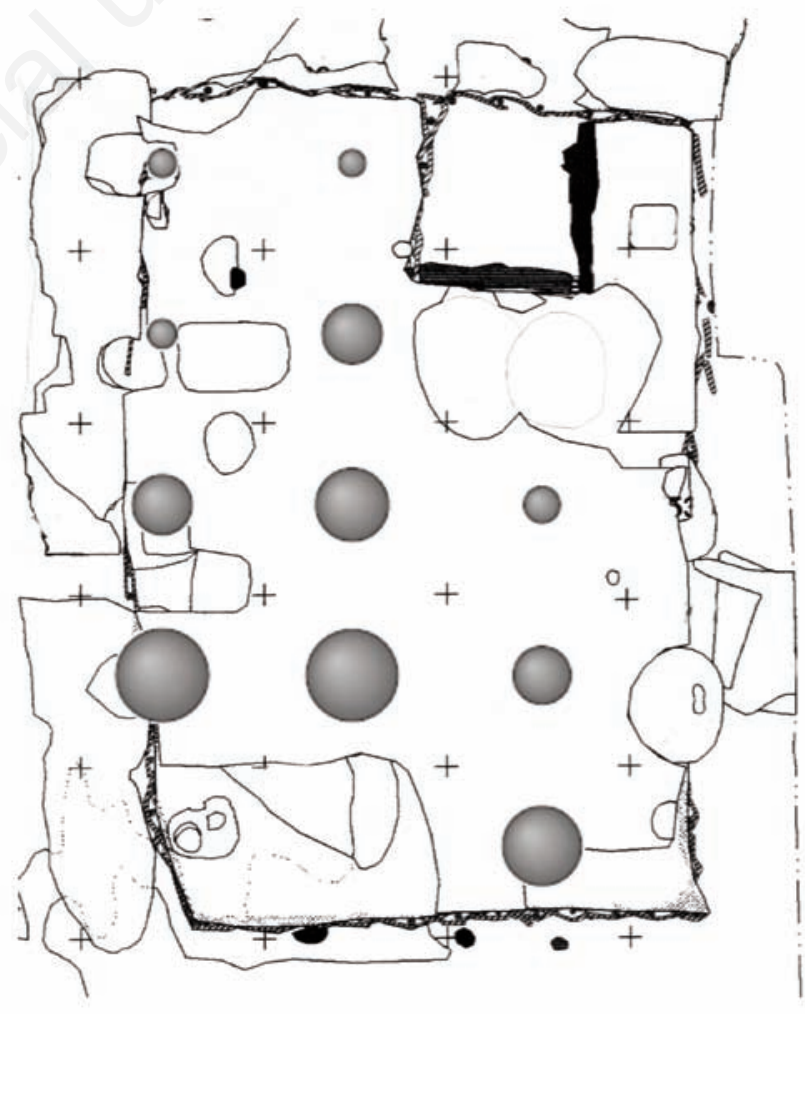

Figure 9. The distribution of lead droplets in the winter 1022 1023. 


\section{Conclusions}

The combination of single context excavation, systematic sampling and the close collaboration of archaeology, archaeobotany, dendrochronology and archaeometallurgy has proven to make it possible to give an account of the development and use of a workshop in detail.

Originally just thought to be an ordinary smithy, the workshop proved to have a seasonal character, only being used for a limited period during the winter season. Furthermore the workshop was not just used for iron working but also for bronze, silver and probably lead casting as well as probably for comb making. The pattern of use seems to indicate that the workshop was established just to be there in case it was needed. This view is emphasised by the fact that the workshop was apparently kept in repair for a couple of years without being used, before it was finally torn down. This leads to the conclusion that it must have been established on the bidding of a person with great influence. The year of construction and the amount of silver worked in and around the workshop points to King Canute. The king probably toured the country most of the year, and might have visited Viborg in connection with the annual gathering of the Thing taking place here.

\section{References}

Daly A, 2005. Dendrochronological datings and species determination of wood from Viborg Søndersø. In: Mette I, Robinson D,
Hjermind J, Christensen C (eds.), Viborg Søndersø II. Aarhus University Press, Højbjerg, Denmark.

Kenward H, 2005. Insect and other invertebrate remains. In: Mette I, Robinson D, Hjermind J, Christensen C (eds.), Viborg Søndersø II. Aarhus University Press, Højbjerg, Denmark.

Moltsen, Annine S.A. 2005. [Lag-og makrofossilanalyser]. [Article in Danish]. In: Mette I, Robinson D, Hjermind J, Christensen C (eds.), Viborg Søndersø II. Aarhus University Press, Højbjerg, Denmark.

Thomsen, Turi 2005. [Værkstedet - en bygningsarkæologisk redegørelse]. [Article in Danish]. In: Mette I, Robinson D, Hjermind J, Christensen C (eds.), Viborg Søndersø II. Aarhus University Press, Højbjerg, Denmark. 